\title{
The Effect of Teaching Based on the Purdue Model on Creative Thinking Skills of Students
}

\author{
Arş. Gör. Esra ALTINTAŞ* \\ Marmara Üniversitesi, Atatürk Eğitim Fakültesi, İlköğretim Matematik Öğretmenliği ABD, Göztepe \\ Yerleşkesi, Kadıköy, İstanbul / Türkiye \\ Doç. Dr. Ahmet Şükrü ÖZDEMIR \\ Marmara Üniversitesi, Atatürk Eğitim Fakültesi, İlköğretim Matematik Öğretmenliği ABD, Göztepe \\ Yerleşkesi, Kadıköy, İstanbul / Türkiye

\section{Araş. Gör. Abdülkadir KERPIÇ} \\ Marmara Üniversitesi, Atatürk Eğitim Fakültesi, İlköğretim Matematik Öğretmenliği ABD, Göztepe \\ Yerleşkesi, Kadıköy, İstanbul / Türkiye
}

\begin{abstract}
In this study we aimed to find out the effect of the activity related with the $7^{\text {th }}$ grade mathematics subject "The Arithmetic of Conscious Consumer" for second phase primary students in Turkey by introducing Purdue 3-stage model which is used for gifted students' education and to search whether this activity affects students' creative thinking skills or not. In order to find out these effects, an experimental study has been carried out with 61 students from Capitol Primary School at Uskudar district * Sorumlu Yazar. Tel: +90 5336996091 E-posta: hoca_kafkas@hotmail.com (c) 2013 Kalem Eğitim ve Sağlık Hizmetleri Vakfı. Bütün Hakları Saklıdır.


in Istanbul. While 'The Arithmetic of Conscious Consumer' has been taught to 33 of $7^{\text {th }}$ grade experimental group students by using the activity which has been developed according to Purdue model, the same subject has been taught 28 of $7^{\text {th }}$ grade control group students by using activities as stated in national education curriculum for the said subject. Before and after the study, "Creativity Scale (How Creative Are You?)” was given to the students in every groups. Data collected in line with the aims of the study were analyzed by using Kolmogorov-Smirnov test, independent groups t-test, dependent group t-test and Mann-Whitney $U$ test and then results were shown in tables and interpreted. Research findings in view of the results showed that there was a significant difference in creativity test scores in favour of experimental group in creativity post-test average scores between control and experimental groups.

Key Words: Creativity; Creative thinking; Purdue model.

\title{
Purdue Modeline Dayalı Öğretimin Öğrencilerin Yaratıcı Düşünme Becerilerine Etkisi
}

\begin{abstract}
Özet
$\mathrm{Bu}$ çalışmada üstün yetenekli öğrencilerin eğitimi için kullanılan Purdue 3 aşamalı model tanıtılarak, Türkiye'deki ortaokul seviyesindeki öğrenciler için 7. sınıf Bilinçli Tüketim Aritmetiği konusuyla ilgili bu modele dayalı geliştirilen aktivitenin etkisini tespit etmek ve bu aktivitenin öğrencilerin yaratıcı düşünme becerilerini geliştirip geliştirmediğini tespit etmek amaçlanmıştır. Bu etkileri ortaya çıkarmak için İstanbul'un Üsküdar ilçesinde yer alan Capitol İlköğretim Okulu'ndaki 61 öğrenciyle deneysel bir çalışma gerçekleştirilmiştir. Bilinçli Tüketim Aritmetiği konusu deney grubundaki 33 öğrenciye Purdue modeline dayalı olarak geliştirilen bir aktivite kullanılarak anlatılmıştır. Aynı konu 28 kontrol grubu öğrencisine konuyla ilgili Milli Eğitim müfre-
\end{abstract}


datında yer alan etkinlikler kullanılarak anlatılmıştır. Uygulama öncesi ve sonrası yaratıcılık ölçeği (Ne kadar yaratıcısınız?) iki gruba da uygulanmıştır. Çalışmanın amacı kapsamında toplanan veriler Kolmogorov-Smirnov testi, bağımsız grup t-testi, bağımlı grup t-testi ve Mann-Whitney U testi kullanılarak analiz edilmiştir ve sonuçlar tablolar halinde gösterilerek yorumlanmıştır. Elde edilen sonuçlar göstermektedir ki, kontrol ve deney grubunun yaratıcılık son test puanları arasında deney grubu lehine anlamlı bir farklılık vardır.

Anahtar Kelimeler: Yaratıcılık; Yaratıcı düşünme; Purdue model.

\section{Introduction}

Rapid developments and technological changes have been affecting all people. Especially, there has been a great competition among nations for raising creative human models. The man who will keep up with rapidly changing developments should have a creative nature so that he or she can use technology and environmental opportunities most effectively, know and express him or herself successfully, so he or she should be long sighted individual and an active (Ömeroğlu and Turla, 2001).

Creativity is a skill which is necessary in every part of life. Creativity has been treated from a narrow perspective by thinking that it has only been related with art subjects. However, creativity can not be only seen under art subjects but within all sciences and daily life (Çubukçu and Dündar, 2009).

Creativity means that something has been completely new, 
something has never been done before, and a brand new product. People who study on the subject of creativity believe that it has been as a result of ordinary thinking processes. This view explains that everybody can improve creativity skills up to a certain degree. That is, creativity can also be improved later (Treffinger, 1980). On the other hand, creativity is not only producing an brand new product but also it is the ability to synthesize from existing knowledge, to produce different solution suggestions to problems, to adapt into new situations easily and to think different usages and functions of objects other than their existing usage (Y1ldırım, 2007).

Creativity is the work of finding the unknown in every field and being able to come up with different and original solutions to each new problem. It is also the ability to relate concepts that are unrelated to each other (Brockman, 1993 cited in Tekin and Karasu 2009). Torrence (1962) defined creativity as the ability to make new products, develop new and original thoughts, form new lives and experiences by establishing connections between unformed relations.

The general idea that creativity comes naturally is common. However, recent studies show that creativity increases proportionally with the factors like intelligence, talent, environment and education (Yenilmez and Yolcu, 2007). Using mental skills for creating a new product is one of the most effective activities of mankind. For this reason, creativity is the research subject of many scientists and artists. Especially, studies on how to improve creativity are being carried out (Erdoğdu, 2006). 
Improving creative thinking has a role in improving all the mental activities and it helps individuals to adapt into new situations as well as to gain communication skills (Yenilmez and Yolcu, 2007).

Nowadays, it has been tried to find new methods and strategies for improving creativity. The purpose here is to provide learning creativity instead of teaching creativity. Because, creativity is not a skill which can be taught easily and it can be taught in an intellectual atmosphere by experiencing, feeling and questioning the existing environment (Yalçın Çelik and Aydınlı, 2008).

Individuals have considerable differences in their abilities in terms of creativity. Such individuals who have more creative capacity than others produce more original and different ideas and they are tend to display more flexible and free thoughts than who have less creative capacity. They are curious, independent, interested in basic problems, energetic. They have also sense of humor, can establish connections and see the relationships (Yenilmez and Yolcu, 2007; Morris, 2006; Y1ldırım, 2007).

Teachers have great responsibilities for improving creativity, because only they can help their students to improve their students' creativity by using such a language that encourages creativity and by establishing an environment for supporting students' creativity efforts. All the students have a creative potential and it is necessary to reveal and improve this potential by establishing proper environments (URL, 2012). 
In order to improve creativity in classroom environments, teachers should establish a ground where the students can express their thoughts. Also they should respect every opinion expressed by the students. They should not focus on a single answer. They should avoid creating doubtful situations. They should not expect logical answers constantly and the most important thing, is that they should make their students feel appreciated when they are creative (Yenilmez and Yolcu, 2007).

It is very important to recognize creativity in the early ages of childhood and to offer educational opportunities to them in this way. Especially, it is important to determine a primary school child’s creative thinking levels. In this respect, teachers have very important roles (Ersoy and Başer, 2009).

Creativity is available to improve as and when it finds proper environments. For this reason, parents educational institutions and in short all the society should be informed about their effect on creativity, so that important steps could be taken for improving creativity (Milne, 1996).

Educational systems should provide opportunities to students for improving their potential, critical thinking skills and acquiring scientific thinking skills. Students are provided to find intellectual improvement opportunities with suitable arrangements in their educational programs (Emir, 2001). As we consider that primary school process is the most critical period where the students rapidly change 
and perform improvement both in terms of physical and mental aspects and also they are shaped both in academic and socio-cultural aspects, the importance of educational programs is coming into sight more clearly in this period (Aydın and Ceran, 2010).

One of the basic critiques for compulsory education and general education system is related with obstacles before the improvement of creativity (Amabile, 1998; Doğan, 2005). Hennessey and Amabile stated the five factors that effect creativity as follows: Children's work for a reward, the creation of competitive environments, children's focus on expected evaluations, using multiple observations and presenting limited number of options (cited in Fasko 2001). It is necessary to rearrange the content and teaching methods in order to promote skills like critical thinking, scientific thinking, relational thinking, reasoning and creative thinking in the education systems for upgrading the students' potential capacities (Doğan, 2005).

The characteristics, needs and purposes of gifted students have been used as a guide for developing Purdue three-stage model in giving education to gifted students in primary level. Stage-1 of the Purdue 3-stage model is used as a basis for teaching basic thinking skills like fluency, flexibility, originality, imagination and asking questions. Stage-2 is used for teaching more complex thinking strategies like logical inference, critical thinking and creative problem solving. Stage-3 includes independent, individual learning and project activities starting from early stages of development of children indented for creative production in adulthood. The characteristics and needs of 
gifted children are used for guiding educational activities in Purdue 3-stage model (Feldhusen and Kolloff, 1986). The model which is used for gifted students has been applied to the regular students in this research. The activities designed by the researchers based on Purdue model have been applied to the regular students by without making any change.

As a result of scanning literature of studies, it has been found that there is a relation with the subjects that creative and critical thinking based learning activities improves creative thinking skills (Koray, 2004; Karataş and Özcan, 2010; Altındağ, Göksel, Koray and Koray, 2012), cooperative learning and cooperative problem solving environments which improve creative thinking skills (Kaptan and Korkmaz, 2002; Birişçi and Karal, 2011) and problem based learning environments improve creativity (Yaman and Yalçın, 2004). Besides, it has been found that there is no significant difference between male and female students’ creative thinking skills (Öncü, 2000; Öncü, 2003; Demirbaş, 2005).

By moving from these explanations, we can express the problem statement of the study as the follows: "Is there an effect of the activity which is developed according to Purdue 3-stage enrichment model about the subject of The Arithmetic of Conscious Consumer on the creativity of $7^{\text {th }}$ grade students?”

The purpose of this study is to investigate the effect of the instructional activity related with the subject of The Arithmetic of Con- 
scious Consumer at $7^{\text {th }}$ grade regular students in Turkey by introducing Purdue 3-stage model which is used for gifted students and to find out whether this activity affects students’ creative thinking skills or not.

In accordance with the purpose of this study, the answers of the following sub-problems have been searched in the study conducted for the $7^{\text {th }}$ grade primary students.

1. Is there a significant difference between control and experimental groups’ achievement pre-test results?

2. Is there a significant difference between control and experimental groups' creativity pre-test results and post-test results?

3. Is there a significant difference between control group's creativity pre-test and post-test results?

4. Is there a significant difference between experimental group's creativity pre-test and post-test results?

5. Do the creative thinking skills of experimental group differ by gender after application?

\section{Method}

\section{Research Model}

In this study, 'pre-test and post-test with a control group model' was used among experiment models as a type of research model. The subject of 'The Arithmetic of Conscious Consumer' was taught to 33 
$7^{\text {th }}$ grade experimental group students by using the activity which was developed according to Purdue model, the same subject was taught 28 $7^{\text {th }}$ grade control group students by using activities stated in national education curriculum for the subject.

The instructional activity was designed by the researchers and controlled by an expert academician in this subject. Besides, the activity was controlled by an academician from Turkish Education and given its final form.

\section{Population and Sample}

The population of the study consists of $7^{\text {th }}$ grade students from primary schools at Uskudar district in Istanbul. The sample of the study consists of 61 students from 7-A and 7-B classes in Capitol Primary School at Uskudar district in Istanbul.

\section{Data Collection Tools}

\section{Mathematical achievement test}

The achievement test which was conducted to students had 42 questions taken from national examinations like OKS, DPY, SBS and Private Schools examinations by paying attention to the objectives of the Arithmetic of the Conscious Consumer subject. These questions were controlled by the researchers, an academician and two mathematics teachers. Achievement test was conducted to approximately 30 $8^{\text {th }}$ grade students from a primary school at Kadikoy district before pilot implementation and the amount of time for performing the test was determined. Later on, the data collected as a result of the pilot study 
which was carried out with $2558^{\text {th }}$ grade students from 10 primary schools at Kadıkoy District were analyzed by using a statistics package and the number of questions were reduced to 31 by looking at the total item, remaining item and item discrimination. Reliability co-efficient of the achievement test was found as 0.803 . It shows that the reliability of the test is high.

\section{Creativity scale (How creative are you?)}

The scale entitled as 'How creative are you?' prepared by Whetton and Cameron (2002) was used to determine the creativity of the students in the study. The version of the scale which was adapted into Turkish by Aksoy (2004) as 'Creativity Scale (How creative are you?)' was used in the study.

Final version of the scale with 40 items was determined by making necessary statistical analysis of the items of the scale. 'I agree, Undecided and I disagree' alternatives were used in the scale for determining the creative peculiarities of the students and the students participated in the study were asked to choose the appropriate alternative for themselves. The scoring of each item used in the scale was different. The lowest point for the items used in the scale was (-2) and the highest point was 4 (Aksoy, 2004).

On the other hand, the $40^{\text {th }}$ question was not in grading scale type. In this question, 54 adjectives related with creativity were given. The points of these adjectives in the scale differ between 0 and 2 . The points of these adjectives were used in calculating total creativity scores of 
each student. According to the points obtained from the scale, the creativity levels were determined by Aksoy (2004) as 'Uncreative' for points less than 10; 'Creative below average' for points between 10-19; 'Average-Creative' for points between 20-39; 'Creative above average' for points between 40-64; 'Very Creative' for points between 65-94; 'Exceptionally Creative’ for points between 95-116 (Aksoy, 2004). The validity and reliability analysis of the test was made with 174 students before. The reliability co-efficient of the test was 0.94 . The minimum point is -2 and maximum point is 30 for 39 items in the scale. The point changes between 0 and 2 for $40^{\text {th }}$ question in the scale (Çınar, 2007). In our study we found the reliability co-efficient as 0.90 .

\section{Application and Sample Selection}

In order to search the effect of the instructional activity designed according to 3-stage enrichment Purdue model for $7^{\text {th }}$ grades in mathematics field about Arithmetic of Conscious Consumer subject on students; $7^{\text {th }}$ grade students in Capitol Primary school were tested. Since there are two classes for $7^{\text {th }}$ grades in this school, by conducting achievement test as pre-test to both classes, it was searched whether groups were homogenous or not. For this purpose, achievement pre-test scores of both groups were compared with two independent sample t-tests. As a result, it was determined that there was no significant difference between achievement pre-test scores of both groups, but the average of achievement pre-test of 7-B was lower than 7-A. In this regard, 7-B class whose achievement average was lower was determined as experiment group and 7-A class was determined as control 
group. There were 33 students in experimental group and 28 students in control group.

\section{Experimental Procedure}

The study lasted 3 weeks. 4 lessons were made with each classes for every week. Achievement test was used as pretest and creative thinking test was conducted with students before and after application. In National Education curriculum 6 hours were given to the subject of Arithmetic of Conscious Consumer. In this study, teaching of this subject lasted 6 hours for each class. Meanwhile, during 2 weeks experimental group students prepared projects and after teaching of the subject they presented their projects to their classmates. Researchers explained how projects should be prepared in both classes in 1 course hour. The application of achievement test lasted 2 course hours and another 2 course hours were given for the application of achievement test before the application for each class. The time - period for applying creative thinking test was 25 minutes including the explanation of the test, 50 minutes were given to both classrooms for creative thinking test before and after application. Project presentation lasted 2 hours after the teaching of the subject.

In the $1^{\text {st }}$ stage of the model, activities within the scope of basic and integrated scientific process skills were conducted. At this stage, applications to improve skills for the subject matter were made. In this sense, it was provided for students to observe, classify, anticipate, infer, determine the variables and define the correlations among variables, analyze and hypothesize. 
At the second stage of the model students worked in groups. Students were grouped and asked them to solve problems given by the teacher cooperatively in their groups by brainstorming and discussing and to find out alternative solution proposals and to decide on the most effective solution proposal. Each group was asked to set a spokesman and then told to explain how they solved the problem by writing the solution steps on the board. The problems were related with the daily life and they were formed to let students to create relations between different situations. Besides, students were asked to explain things they had done with reasons. In short, it was acted for improving creative problem solving skills.

At the third stage of the model, students made individual, independent project studies. First how project studies should be prepared was explained to the students. Students were asked to think about their project names from the first week when the application phase of the Arithmetic of Conscious Consumer Subject started. Then they were asked to determine their project subjects by themselves. The researcher did not intervene in the selection of project subjects only by guiding them at this stage. Each student prepared his or her project and project stand according to the project preparation requirements given by the researcher. Feedbacks about the projects were given to the students in less than a day by taking their e-mails and phone numbers. Projects were followed from internet and students were told that they could get information whenever they wanted via internet. Each student had 10 minutes to present his or her project. 


\section{Data Analysis}

In this research the data gathered from control and experimental groups were analyzed by using a statistical analysis program. They were used Kolmogorov-Smirnov test, independent groups t-test, dependent group t-test and Mann Whitney-U test while analyzing data. Significance value was accepted 0.05 in interpreting of data.

\section{Findings and Interpretations}

At this part, findings gathered as a result of the statistical studies were given in tables and these tables were interpreted.

In the table 1 and table 2 below, we examine the normality distribution for all groups. For this purpose we use "Kolmogorov-Smirnov Test” because the number of data for all groups is bigger than 29 .

Table 1. The Normality Tests of Control and Experimental Groups' Creativity Pre-test and Post-test Scores and Achievement Pre-test Scores

\begin{tabular}{llll}
\hline \multicolumn{4}{c}{ Kolmogorov-Smirnov Test } \\
\hline & Statistics & $\mathrm{N}$ & $\mathrm{p}$ \\
Achievement Pre-Test & 0,100 & 61 & 0,200 \\
Creativity Pre-Test & 0,076 & 61 & 0,200 \\
Creativity Post-Test & 0,104 & 61 & 0,100 \\
\hline
\end{tabular}


Table 2. Descriptive Statistics

\begin{tabular}{l|ccc}
\hline \multicolumn{1}{l}{ Statistics } & $\begin{array}{c}\text { Achievement } \\
\text { Pre-Test }\end{array}$ & $\begin{array}{c}\text { Creativity } \\
\text { Pre-test }\end{array}$ & $\begin{array}{c}\text { Creativity } \\
\text { Post-Test }\end{array}$ \\
\hline Mean & 8,40 & 40,77 & 45,66 \\
Median & 8,00 & 41,00 & 45,00 \\
Mode & 6 & 40 & 40 \\
Minimum & 1 & 24 & 27 \\
Maximum & 17 & 64 & 71 \\
Range & 16 & 40 & 44 \\
Skewness &,- 013 &, 372 &, 434 \\
Std. error of Skewness &, 306 &, 306 &, 306 \\
Kurtosis &, 179 &, 144 &,- 061 \\
Std. error of Kurtosis &, 604 &, 604 &, 604 \\
\hline
\end{tabular}

In the table 1 and table 2, normality test of creativity pre test-post test and achievement pre-test applications and descriptive statistics are listed. When the tables are analyzed, it will be seen that the number of data for all groups is bigger than 29. In this situation in order to analyze whether the data is normal or not, Kolmogorov-Smirnov test is used. According to the table 1 and table 2, for each data group, since $p$ significance value of this test is bigger than 0,05 value and for each data, skewness and kurtosis values are between in range -2 and +2 , so it is accepted that all data show normal distribution.

In the table 3 below, we examine if there is a significant difference between pre-test achievement scores of Control and Experimental Groups’ or not. For this purpose we use “Independent Groups T-test”. 
Table 3. The Comparison of Control and Experimental Groups' Achievement Test Pre-Test Scores with Independent Groups T-test

\begin{tabular}{c|cccccc}
\hline Groups & $\mathrm{N}$ & Average & ss & sd & $\mathrm{t}$ & $\mathrm{p}$ \\
\hline Control Group & 28 & 8,750 & 3,026 & \multirow{2}{*}{59} & 0,753 & 0,454 \\
Experimental Group & 33 & 8,121 & 3,425 & & & \\
\hline
\end{tabular}

When the Table 3 is examined, it is seen that there is not a significant difference between pre-test achievement scores of both groups $[t(59)=.753, p>.05]$. According to this, pre-test achievement scores differ according to groups. However, when the average scores are examined, it is seen that there is a little 0,63 points difference in favor of control group between control group’s achievement average score and experimental group’s achievement average score.

In the table 4 below, we examine if there is a significant difference between pre-test creativity scores of Control and Experimental Groups’ or not. For this purpose we use “Independent Groups T-test”.

Table 4. The Comparison of Control and Experimental Groups' Creativity Test Pre-Test Scores with Independent Group T-test

\begin{tabular}{c|cccccc}
\hline Groups & N & Average & ss & sd & t & p \\
\hline Control Group & 28 & 41,714 & 8,343 & \multirow{2}{*}{59} & 0,807 & 0,423 \\
Experimental Group & 33 & 39,969 & 8,468 & & & \\
\hline
\end{tabular}

When the Table 4 is examined, p significance value was found 0,423 as result of the statistical study and since it is bigger than 0,05 , it is seen that there is not a significant difference between pre-test creativity scores of both groups $[t(59)=.807, p>.05]$. According to this, 
pre-test creative scores don't differ according to groups. According to table, it is seen that there is a little 1,6 points difference in favor of control group between creative average scores of control and experiment groups.

In Table 5 below, we examine if there is a significant difference between pre-test creativity scores of Control and Experimental Groups' or not. For this purpose we use “Independent Groups T-test”.

Table 5. The Comparison of Control and Experimental Groups' Creativity Test Post-test Scores with Independent Group T-test

\begin{tabular}{|c|c|c|c|c|c|c|}
\hline Groups & $\mathrm{N}$ & Average & SS & sd & $\mathrm{t}$ & $\mathrm{p}$ \\
\hline Control Group & 28 & 42,392 & 9,772 & \multirow{2}{*}{59} & \multirow{2}{*}{$-2,390$} & \multirow{2}{*}{0,020} \\
\hline Experimental Group & 33 & 48,424 & 9,864 & & & \\
\hline
\end{tabular}

When the Table 5 is examined, it is seen that there is a significant difference between post-test creativity scores of both groups $[t(59)=$ $-.239, p<.05]$. According to the table, it is seen that there is 6,03 points difference in favor of experimental group between creativity post-test average scores of control and experiment groups.

In the table 6 below, we examine if there is a significant difference between pre-test and post-test creativity scores of Control Group or not. For this purpose we use “Dependent Groups T-test”.

Table 6. The Comparison of Control Group's Creativity Test Pretest and Post-test Scores with Dependent Group T-test 


\begin{tabular}{c|cccccc}
\hline Groups & $\mathrm{N}$ & Average & ss & sd & $\mathrm{t}$ & $\mathrm{p}$ \\
\hline Pre-Test & 28 & 41,714 & 8,343 & 27 & $-0,414$ & 0,682 \\
Post -Test & 28 & 42,392 & 9,772 & & & \\
\hline
\end{tabular}

When the Table 6 is examined, it is seen that there is not a significant difference between control groups’ pre-test and post-test creativity scores [ $t(27)=-.414, p>.05]$. Pre-test and post-test scores of control group do not differ in terms of creativity.

In the table 7 below, we examine if there is a significant difference between pre-test and post-test creativity scores of Experimental Group or not. For this purpose we use "Dependent Groups T-test”

Table 7. The Comparison of Experimental Groups' Creativity Test Pretest and Post-test Scores with Dependent Group T-test

\begin{tabular}{c|cccccc}
\hline Groups & $\mathrm{N}$ & Average & ss & sd & $\mathrm{t}$ & $\mathrm{p}$ \\
\hline Pre-Test & 33 & 39,969 & 8,4686 & 32 & $-3,454$ & 0,001 \\
Post-Test & 33 & 48,424 & 9,864 & & & \\
\hline
\end{tabular}

When the Table 7 is examined, it is seen that there is a significant difference between pre-test and post-test creativity scores of the group [ $t(32)=-3.454, p<.05]$. It is seen that there is a significant difference between experimental group's creativity scores in favor of the model before and after teaching carried out according to 3-stage Purdue model.

In the table 8 below, we examine if there is a significant differ- 
ence between pre-test creativity scores of girls and boys or not. For this purpose we use "Mann -Whitney U Test” because the number of data for both groups is smaller than 29 .

Table 8. The Comparison of Experimental Groups' Creativity Test Pre-test Scores by Gender with Mann -Whitney U Test

\begin{tabular}{cccccc}
\hline Groups & $\mathrm{N}$ & Mean Ranks & Sum of Ranks & $\mathrm{U}$ & $\mathrm{p}$ \\
\hline Girls & 13 & 20,27 & 263,50 & & \\
Boys & 20 & 14,88 & 297,50 & & \\
\hline
\end{tabular}

When the Table 8 is examined, it is seen that there is not a significant difference between experimental group's pre-test creativity scores by gender $[U(31)=87.500, p>.05]$. Pre-test creativity scores of experimental group do not differ by gender.

In the table 9 below, we examine if there is a significant difference between post-test creativity scores of girls and boys or not. For this purpose we use "Mann-Whitney U Test" because all number of data both groups is smaller than 29 .

Table 9. The Comparison of Experimental Groups' Creativity Test Post-test Scores by Gender with Mann-Whitney U Test

\begin{tabular}{cccccc}
\hline Groups & $\mathrm{N}$ & $\begin{array}{c}\text { Mean } \\
\text { Ranks }\end{array}$ & $\begin{array}{c}\text { Sum of } \\
\text { Ranks }\end{array}$ & $\mathrm{U}$ & $\mathrm{p}$ \\
\hline Girls & 13 & 17,04 & 221,50 & & \\
Boys & 20 & 16,98 & 339,50 & 129,500 & 0,985 \\
\hline
\end{tabular}


When the Table 9 is examined, it is seen that there is not a significant difference between experimental group's post-test creativity scores by gender $[U(32)=129.500, p>.05]$. Post- test creativity scores of experimental group do not differ by gender.

\section{Conclusion and Suggestions}

Within the scope of this study, Arithmetic of Conscious Consumer subject which was used in $7^{\text {th }}$ grades was taught by using activities designed according to Purdue 3-stage enrichment model to the experimental group and it was taught to control group by using activities related with this subject as they were stated in the national education curriculum.

When the findings gathered as a result of this study were analyzed, it was seen that creativity scores of experimental group students who were taught with the help of activities designed according to Purdue 3- stage enrichment model was higher than control group students who were taught with the help of activities related with this subject as they were stated in the national education curriculum. While there is not a significant difference between creativity scores before application, there is a significant difference in favor of experimental group between creativity scores of experimental and control group students after application. At this point, it can be said that teaching with the help of activities based on Purdue model is more effective than teaching with the help of activities stated in National Education Curriculum for improving creative thinking skills of students. Because, 
students performed studies like cooperation in problem solving, project-based learning and problem based learning with Purdue 3- stage enrichment model and the lesson was carried out according to the components of creativity. In addition to that, in the lesson which was carried out with the help of activities based on model, discussions and subject-based teaching of critical thinking skills were used and as the lesson was carried out by using research, discussion and question-answer techniques, students opinions were taken on each matter and individual project studies were made, creative thinking skills of experimental group students improved. This situation is parallel with the studies of Kaptan and Korkmaz (2002), Yaman and Yalçın (2004), Koray (2004), Karataş and Özcan (2010), Birişçi and Karal (2011), Altındağ, Göksel, Koray and Koray (2012) because creative and critical thinking based learning improves creative thinking skills

According to the findings, although both control and experimental group students' creativity scores increased, and a significant difference was not observed between control group students' pre-test and pos-test creativity scores, it was seen that there was a significant difference between experimental group students' creativity scores before and after the study.

When the creativity scores of experimental group students were examined by gender, it was seen that creativity scores did not differ by gender. However, although there was not a significant statistical difference between creativity scores of boys and girls, it was determined that the increase in boys' creativity scores was higher than girls. The 
situation of creativity scores do not differ by gender is parallel with the studies which were carried out by Öncü in 2000 and 2003 and with the study which was carried out by Demirbaş in 2005 .

Some suggestions can be given related to the study:

The effect of the activity designed according to Purdue model on gifted students’ creative thinking skills should be examined.

It is necessary to provide environments where students can express their opinions freely. Besides, students should feel that their ideas are appreciated. With the help of this, students have the opportunity to present more creative ideas in a freer environment.

Students should be free while determining project subjects. Teachers should stick to their guidance role.

Creating cooperative learning environments especially cooperative problem solving environments is important for students to bring different solution suggestions and to look from different perspectives at the events by interacting with other friends.

Students should especially be asked to explain what they do during the cooperative problem solving phase used at the second stage of the model.

Activities should also be designed according to Purdue model for the different subjects in teaching mathematics and the effect of these activities on achievement and creative thinking skills should be ex- 
amined.

\section{References}

Aksoy, B. (2004). Coğrafya öğretiminde probleme dayalı öğrenme yaklaşımı. Unpublished PhD thesis, Gazi Üniversitesi.

Altıntağ, C. Göksel, Ç. Koray, Ö., \& Koray, A. (2012, June). Eleştirel ve yaratıcı düşünme temelli fen ve teknoloji laboratuarı uygulamalarının problem çözme ve yaratıcllı üzerine etkisi. X. ulusal fen bilimleri ve matematik ĕgitimi kongresi, Niğde.

Aydın Ceran, S. (2010). Yaratıcı düşünme teknikleri ile geliştirilen fen etkinliklerinin öğrenci başarısı ve tutumuna etkisi. Unpublished MA thesis, Selçuk Üniversitesi.

Birişçi, S., \& Karal, H. (2011). Öğretmen adaylarının bilgisayar destekli ortamda materyal tasarlarken işbirlikli çalışmalarının yaratıcı düşünme becerilerine etkisi. Ahi Evran Üniversitesi Eğitim Fakültesi Dergisi, 12(2), 203-219.

Çınar, D. (2007). İlköğretim fen ĕgitiminde probleme dayalı öğrenme yaklaşımının üst düzey düşünme becerilerine ve akademik risk alma düzeyine etkisi. Unpublished MA thesis, Selçuk Üniversitesi.

Çubukçu, E., \& Dündar, Ş. G. (2007). Can creativity be taught? An empirical study on benefits of visual analogy in basic design education. $A \mid Z$ ITU Journal of the Faculty of Architecture, 4(2), 67-80. 
Demirbaş, A. (2005). Biyoloji öğretiminde yaratıcı yazma uygulamaları. Unpublished MA thesis, Balıkesir Üniversitesi.

Doğan, N. (2005). Yaratıcı düşünme ve yaratıcılık. In Ö. Demirel, (Ed.), Eğitimde Yeni Yönelimler (pp. 163-188). Ankara: Pegem A Yayıncılık.

Emir, S. (2001). Sosyal bilgiler öğretiminde yaratıcı düşünmenin erişiye ve kalıcılı̆̆a etkisi. Unpublished $\mathrm{PhD}$ thesis, Hacettepe Üniversitesi.

Erdoğdu, M. Y. (2006). Yaratıcılık değerlendirme ölçeğinin türk kültürüne uyarlanması. İn̈nü Üniversitesi Eğitim Fakültesi Dergisi, 7(12), 61-79.

Ersoy, E., \& Başer, N. (2009). İlköğretim

6. sınıf öğrencilerinin yaratıcı düşünme düzeyleri. The Journal Of International Social Research, 2(9), 129-137.

Fasko, D. Jr. (2001). Education and creativit. Creativity Research Journal, 13(3,4), 317-327.

Feldhussen, J., \& Kolloff, P. B. (1986). The purdue three-stage enrichment model for gifted education at the elementary level. In J.S. Renzulli, (Ed.), System and models for developing programs for the gifted and talented (pp. 126-152). Mansfield Center, CT: Creative Learning Press.

Kaptan, F., \& Korkmaz, H. (2002). The effects of cooperative problem solving approach on creativity in science course. Journal of Qafqaz University, 1(99), 143-150. 
Karasar, N. (2009). Bilimsel araştırma yöntemi. Ankara: Nobel.

Karataş, S., \& Özcan, S. (2010). Yaratıcı düşünme etkinliklerinin öğrencilerin yaratıcı düşünmelerine ve proje geliştirmelerine etkisi. Kırşehir Eğitim Fakültesi Dergisi, 11(1). 225-243.

Koray, Ö. (2004). Fen eğitiminde yaratıcı düşünmeye dayalı öğrenmenin öğretmen adaylarının yaratıcılı düzeylerine si. Kuram ve Uygulamada Eğitim Yönetimi Dergisi, 10(40), 580-599.

Milne, P. A. (1996). Generic skills, group work and the world wide web: Ingredients for a creative teaching and learning experience. Education for Library and Information Services: Australia, 13(3), 21-36.

Morris, W. (2006). Creativity - its place in education. Retrieved from http://www.jpb.com/creative/creativity_in_education.pdf.

Ömeroğlu, E., \& Turla, A. (2001). Okul öncesi dönemde yaratıcılık eğitimi ve desteklenmesi. Milli Ĕ̆itim Dergisi, 151, 49-53.

Öncü, T. (1992). Yaratıcılığın betimlenmesi ve yaratıcılık üzerine çevresel etkiler. Ankara Üniversitesi Dil ve Tarih-Coğrafya Fakültesi Felsefe Bölümü Dergisi, 14(1), 255-264.

Öncü, T. (2000). Anasınıfı (6 yaş) düzeyindeki çocukların şekilsel yaratıcılıklarının cinsiyet değişkeni açısından karşılaştırılması. Ankara Üniversitesi Dil ve Tarih-Coğrafya Fakültesi Dergisi, 40(1), 25-34.

Öncü, T. (2003). Torrance yaratıcı düşünme testleri-şekil testi aracıl1- 
ğıyla 12-14 yaşları arasındaki çocukların yaratıcılık düzeylerinin yaş ve cinsiyete göre karşılaştırılması. Ankara Üniversitesi Dil ve Tarih Coğrafya Fakültesi Dergisi, 43(1), 221-237.

Seltzer, K., \& Bentley, T. (1999). The creative age: Knowledge and skills for the new economy. London: Demos.

Tekin, M., \& Karasu, M. (2009, May). Üstün yetenekli öğrencilerin yaratıcılık düzeyleri ve problem çözme becerilerinin incelenmesi (Ankara il örneği). I. uluslararası eğitim araştırmaları kongresi, Çanakkale.

Torrance, E. P. (1962). Guiding creative talent. Englewood Cliffs, New Jersey: Prentice Hall Inc.

Treffinger, D. J. (1980). Encouraging creative learning for the gifted and talented. Ventura, CA: Ventura County Schools/LTI.

Yalçın Çelik, P., \& Aydınlı, S. (2008). Creativity in design education: from problem-solving to puzzle-solving. A|Z ITU Journal of the Faculty of Architecture, 4(2), 38-51.

Yaman, S., \& Yalçın, N. (2005). Fen bilgisi öğretiminde probleme dayalı öğrenme yaklaşımının yaratıcı düşünme becerisine etkisi. İlkögrretim Online, 4(1), 42-52.

Yenilmez, K., \& Yolcu, B. (2007). Öğretmen davranışlarının yaratıc1 düşünme becerilerinin gelişimine katkısı. Sosyal Bilimler Dergisi, 18, 95-105.

Yıldırım, E. (2007). Bilgi çağında yaratıcılığın ve yaratıcılığ̣ yönetmenin önemi. Selçuk Üniversitesi Karaman IIIBF Dergisi, 
12,109-120.

(n.d.) . Retrieved June 24, 2012, from

http://www.download.intel.com/education/common/tr/resource s/dep/skills/dep_creativity.doc. 